\title{
Pancreatic Beta Cell Lines and their Applications in Diabetes Mellitus Research
}

\author{
Masa Skelin ${ }^{1}$, Marjan Rupnik ${ }^{1}$ and Avrelija Cenci $\check{c}^{1,2}$ \\ ${ }^{1}$ Faculty of Medicine, University of Maribor, Slovenia; ${ }^{2}$ Faculty of Agriculture and Life Sciences, University \\ of Maribor, Slovenia
}

\begin{abstract}
Summary
During the past 30 years great effort has been put into establishing an insulin-secreting beta cell line that retains normal regulation of insulin secretion, but only few of these attempts have been successful. To overcome the limited availability of primary beta cells and to include the principles of the $3 R$ s into the field of diabetes mellitus research, numerous investigators used X-rays or viruses to induce insulinomas, in vitro transformation, derivation of cells from transgenic mice or even non-islet cells to produce immortalised beta cell lines. The most widely used insulin-secreting cell lines are RIN, HIT, MIN, INS-1 and BTC cells. These cells produce insulin and small amounts of glucagon and somatostatin. Some of them are only poorly responsive to glucose, others respond to glucose well, but their concentration-dependence curve is markedly shifted to higher sensitivity. Despite problems associated with beta cell cultures, these cell lines have provided some valuable information about physiological processes. However, an urgent need to establish a "normal" beta cell line of human or pig origin remains.
\end{abstract}

Keywords: pancreas, beta-cell lines, insulin secretion, insulinoma, SV 40

\section{Introduction}

The use of primary beta cells in biochemical and molecular research is limited by the availability of pancreatic endocrine tissue. Initial isolation of individual pancreatic cells, cell purification and the maintenance of native characteristics is technically demanding. Research in this area is limited also by cellular and hormonal heterogeneity among different individuals.

We should strive to include the principles of 3 Rs into basic research (Gruber and Hartung, 2004), also into the field of diabetes mellitus research. Cell lines represent an animal-free opportunity to study physiological and pathophysiological processes in different cell types. Cell lines can be used to investigate physiology or biochemistry of cells, to test the effects of various chemical compounds or drugs on specific cell types and to synthesise valuable biologicals like therapeutic proteins.

Cell cultures may be derived from primary explants or dispersed cell suspensions. Induced cell proliferation enables the propagation of highly uniform cell lines. Cell tissue culturing requires a number of special skills to ensure the preservation of the structure, function, behaviour and biology of the cells in culture. Immortal cell lines have been used to analyse protein functions and to examine the effects of exogenous protein expression on cell signalling or transcriptional events.

The major advantage of using cell culture is the consistency and reproducibility of results that can be obtained from using a batch of clonal cells. On the other hand there are also some important disadvantages associated with cell lines, including change of cell characteristics over a period of continuous growth. The ability of many of these cell cultures to grow without limits is related to their tumour origin, and these cells may have abnormal chromosomal content, other genetic mutations, abnormal protein expression and modified metabolism.

Cell culture offers many research possibilities, including testing the effects of certain drugs or toxins under various con ditions. Furthermore, cells can be manipulated by transfection to investigate the role of various genes or malignancy of the cells. Cell culture can likewise be used to test a patient's tu mour cell sensitivity to specific cytotoxic agents in vitro as well as in vivo after tumour cell transplantation into an appropriate animal (Ulrich et al., 2002).

On the other hand, one of the problems associated with the cell culture results from disruption of cell to cell interaction, which certainly influences cellular functions in the organism and has some known and still-unknown consequences. Furthermore, genetic manipulation of the cells adds additional problems and can ultimately alter some native functions and responses of the cell, which is probably one of the reasons why most pancreatic beta cell lines have defective secretory characteristics and are unable to respond to glucose in the physi ological range. 


\section{Physiology of beta cells}

An adult mammalian pancreas is composed of an exocrine and an endocrine part, the latter containing groups of cells, the islets of Langerhans, which play a key role in maintaining the appropriate level of nutrients in the blood and cellular depots (Jo et al., 2007). The islets of Langerhans (Fig. 1) consist of insulin-releasing beta cells (65-90\%) forming the core of the islet, glucagon-releasing alpha-cells (15-20\%), somatostatin-producing delta-cells (3-10\%), and pancreatic polypeptide-producing PP-cells (1\%) are usually located on the surface (Elayat et al., 1995). Of these, beta cells, which couple nutrient metabolism with electrical activity to modulate the synthesis and release of insulin, have been most frequently studied.
In humans, insulin promotor factor 1 (IPF-1) is the most important transcription factor involved in specific differentiation of pancreatic beta cells and in induction of insulin secretion. After the fourth week of embryonic development isolated clumps of endodermal cells bud from the tubules and accumulate within the mesoderm to form islet cells (Dudek, 2007). They secrete insulin after the tenth week.

Turnover of adult beta cells is a slow process, since only about $1 \%$ of cells enter into the mitotic phases $\mathrm{G}_{1}, \mathrm{~S}, \mathrm{G}_{2}$ in $\mathrm{M}$ from resting $\mathrm{G}_{0}$ phase (Berne, 1998). New beta cells likely originate from precursors that secrete IPF-1 in the pancreatic duct. Different growth factors, including epidermal growth factor, transforming growth factor $\alpha$, growth hormone and insulin growth factor-1, are involved in beta cell renewal and growth. In addi-

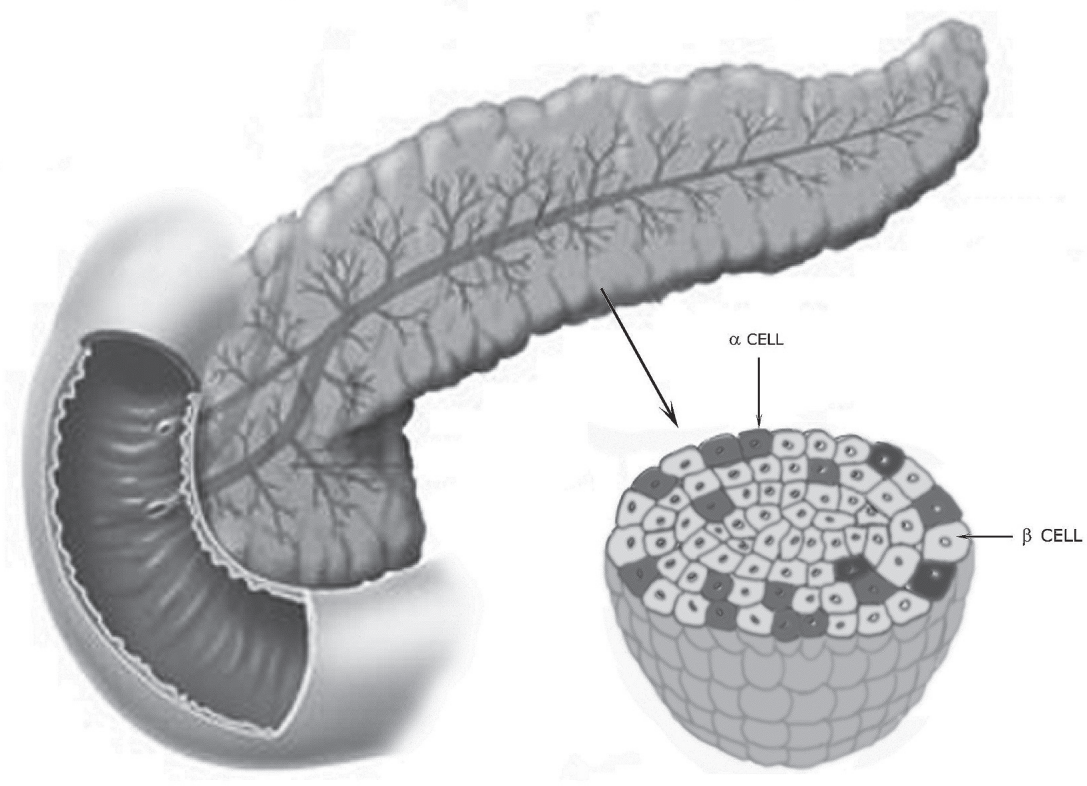

Fig. 1: Structure of the pancreatic islet

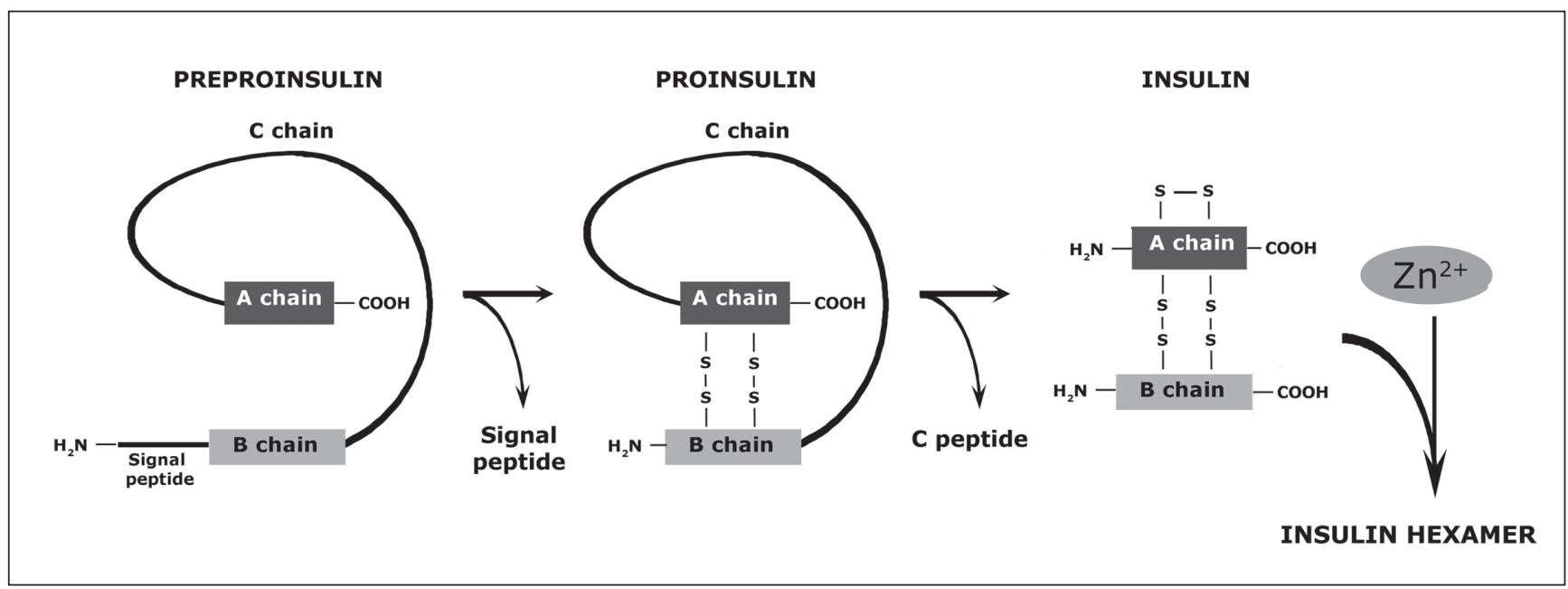

Fig. 2: Insulin biosynthesis 
tion to mitogenesis stimulation, glucose is also able to stimulate beta cell proliferation and destruction. Glucose thereby maintains the adequate amount of beta cells, which is important for overall regulation of metabolism.

Insulin is produced by the beta cells in response to an elevated blood nutrient concentration. The insulin gene is composed of four exons and two introns. The hormone's precursor (preproinsulin), with $1150 \mathrm{Da}$, carries a signal peptide that directs the peptide chain to the interior of the endoplasmic reticulum (ER) and

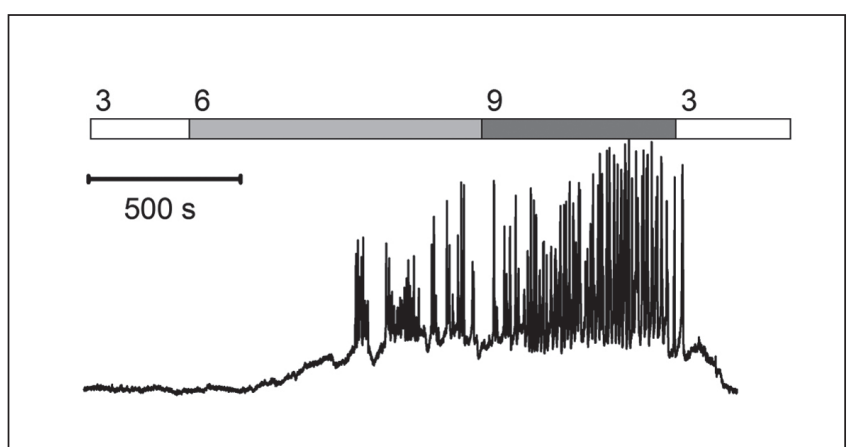

Fig. 3: Glucose-stimulated electrical activity recorded from a beta cell in an intact islet when glucose concentration was increased from 3 to $9 \mathrm{mM}$ contains four peptides: N-terminal signal peptide, B chain, C peptide and A chain (Fig. 2). Proinsulin is produced in the ER by the cleavage of the signal peptide and formation of disulfide bonds. Proinsulin passes to the Golgi apparatus where it is packed into vesicles. After cleavage of the $\mathrm{C}$ peptide, mature insulin is formed in the vesicles and is stored in the form of zinc-containing hexamers until secretion (Koolman and Röhm, 2005).

Glucose is the principal physiological insulin secretagogue and a potent regulator of beta cell activity. Since Dean and Matthews (Dean and Matthews, 1968) first described pancreatic beta cell electrical activity, extensive experiments reveal that a glucose concentration higher than $7 \mathrm{mM}$ results in depolarisation of the cell membrane from the resting potential (about -70 $\mathrm{mV}$ ) up to a threshold from which a rhythmic electrical activity called bursting is elicited. Bursting consists of an active phase of $\mathrm{Ca}^{2+}$-dependent action potentials and the subsequent hyperpolarised silent phase. The duration of the active phase increases with increasing glucose level (Fig. 3).

Insulin secretion is initiated by an increase in cytoplasmic calcium concentration $-\left[\mathrm{Ca}^{2+}\right] \mathrm{i}$ (Fig. 4). In the absence of glucose, the cytoplasmic ATP concentration is too low to keep the ATP-sensitive K-channels (KATP) closed. When the extracellular glucose concentration is elevated, glucose enters the cells through GLUT2 transporters, and metabolic degradation of glucose increases production of ATP that is responsible for closing

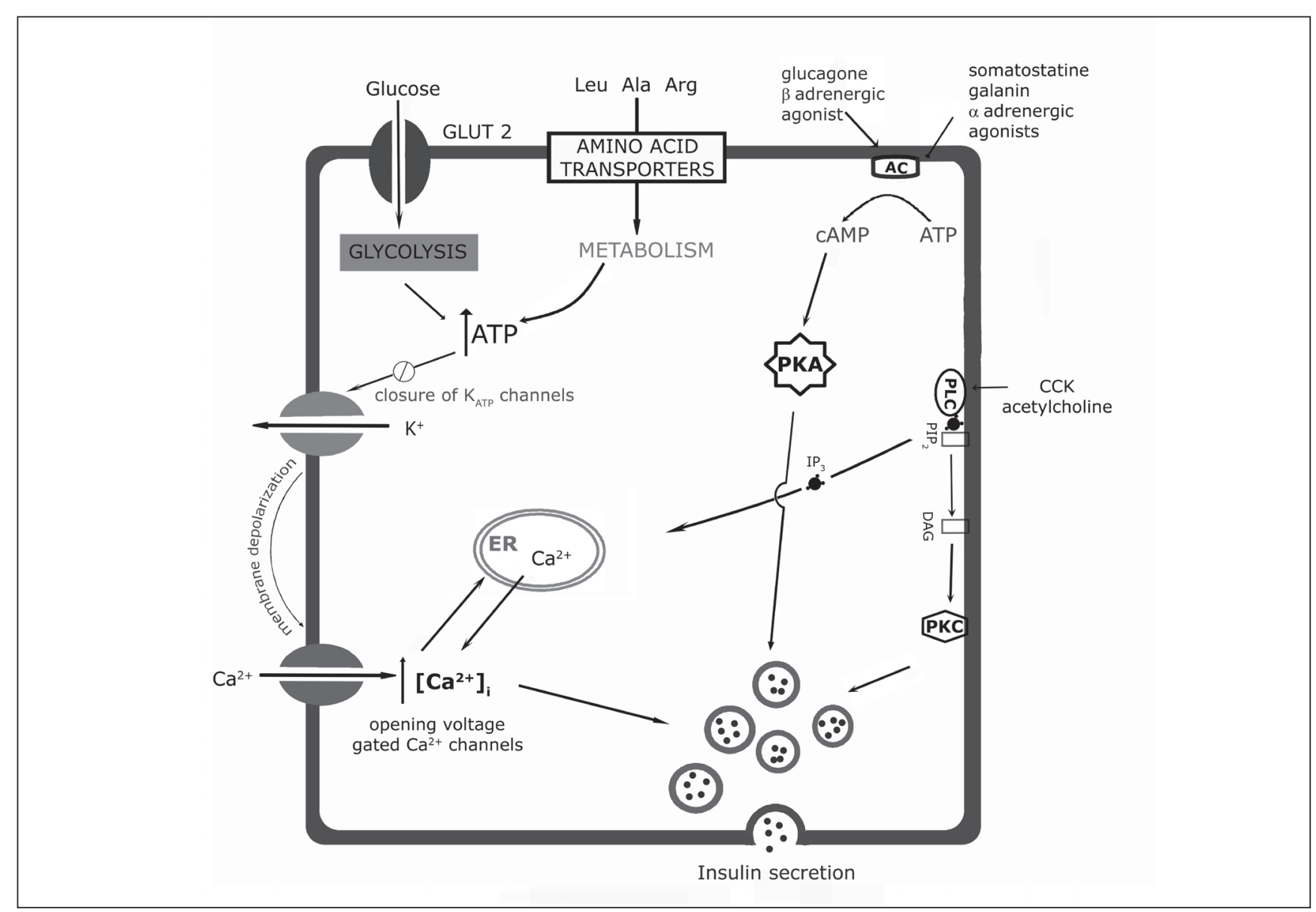

Fig. 4: Action of glucose, amino acids and neurotransmitters on insulin secreting beta cells 
$\mathrm{K}_{\text {ATP }}$ in the plasma membrane, thereby depolarising the plasma membrane, which results in opening of voltage-gated $\mathrm{Ca}^{2+}$ channels and increased influx of extracellular $\mathrm{Ca}^{2+}$. Electrical activity together with $\mathrm{Ca}^{2+}$ influx occurs in bursts and results in insulin release (Ashcroft and Rorsman, 1989).

\section{Isolation of primary beta cells}

A primary beta cell culture is usually derived either by enzymatic or mechanical dispersal of the tissue. The most frequently used enzymes are crude preparations of trypsin, collagenase, elastase, hyaluronidase, pronase, DNase, dispase, alone or in various combinations. The most common enzyme used in tissue disaggregation is trypsin, which is effective for many tissues, and any residual activity can be neutralised by serum or by the specific trypsin inhibitor. Another very frequently used enzyme for tissue disaggregation is collagenase, since the extracellular matrix often contains collagen. It is used for very fibrous or sensitive tissues where trypsin is not the method of choice (Freshney, 2000). Collagenase is usually heterogeneous, containing more than 30 different enzymes, pigments and often also endotoxins. In contrast to traditional collagenase, liberase is more homogenous and free of endotoxins and can also be used in many tissues.

In our laboratory primary mouse beta cells are used to study detailed regulated exocytosis by whole-cell patch-clamp technique, which enables us to measure membrane capacitance $\left(\mathrm{C}_{\mathrm{m}}\right)$, a parameter that is proportional to membrane surface area (Neher and Marty, 1982). Our protocol involves isolation (Kwan et al., 2006) of mouse islets of Langerhans with liberase and dispersion of islet cells (Paulmann et al., 2009). In contrast to traditional collagenase, liberase is more homogenous, free of endotoxins and can be used on many tissues.

For isolation of primary beta cells adult mice are killed by cervical dislocation. Liberase $\mathrm{CL}^{\circledR}\left(0.3 \mathrm{mg} \mathrm{ml}^{-1}\right.$, Roche) dissolved in Hank's buffered salt solution (HBSS, supplemented with $10 \mathrm{mM}$ Hepes and $10 \mathrm{U} \mathrm{ml}^{-1}$ penicillin and $0.05 \mathrm{mg}$ $\mathrm{ml}^{-1}$ streptomycin, Invitrogen ${ }^{\mathrm{TM}}$ ) is injected into the pancreas through a bile duct. The pancreas is removed and digested for $10-15 \mathrm{~min}$ at $37^{\circ} \mathrm{C}$. Then $10 \mathrm{ml}$ of HBSS is added to the solution to terminate digestion. Islets are collected by centrifugation, thrice at $3000 \mathrm{rpm}$ for $1 \mathrm{~min}$, every time washed with $10 \mathrm{ml}$ fresh HBSS. Hand-picked isolated islets are trypsinised ( $0.05 \%$ trypsin, $3 \mathrm{~min})$ into single cells, plated onto coverslips $(10 \mathrm{~mm}$ x $10 \mathrm{~mm})$ and cultured in RPMI 1640 medium (Gibco) supplemented with $10 \%$ fetal bovine serum, 2 mM L-glutamine (Sigma-Aldrich), $100 \mathrm{IU} / \mathrm{ml}$ penicillin $\mathrm{G}$ and $0.1 \mathrm{mg} / \mathrm{ml}$ streptomycin (Sigma-Aldrich) in a humidified atmosphere with 5\% $\mathrm{CO}_{2}$ and $95 \%$ air at $37^{\circ} \mathrm{C}$. The primary cell culture can be used for more than a week.

\section{Creation of beta cell lines}

Most cells have a finite life span of 20-100 generations, but some cells can produce continuous cell lines with an infinite life span (Freshney, 2000). The finite life span of cells in culture is regulated by a group of 10 or more dominantly acting senescence genes, the products of which negatively regulate cell cycle progression. Deletion and/or mutations within senescence genes, or overexpression or mutation of one or more oncogenes that override the action of the senescence genes, can allow cells to escape from the negative control of the cell cycle and to reexpress telomerase (Freshney, 2000). The primary cause of senescence appears to be telomeric shortening, telomeres being the distal end of chromosomes composed of tandem repeats of the specific sequence. The function of telomeres includes prevention of chromosome degradation, end-to-end fusions, rearrangements and chromosome loss. Telomeres in somatic cells undergo progressive shortening with cell division through replication-dependent sequence loss at DNA termini. The shortening of telomeres results in chromosomal instability, and critically short telomeres induce cell cycle arrest also known as replicative senescence.

Since primary beta cells do not proliferate easily in culture, numerous investigators have attempted to establish an insulinsecreting cell line that retains normal regulation of insulin secretion and possesses the same genotype and tissue markers of its parental tissue.

A number of growth factors are known to be mitogenic to beta cells (Soria et al., 2000), but they do not allow massive cell expansion in culture.

Some cells immortalise spontaneously by passing through replicative senescence. They easily adapt to life in culture but have unstable genotypes and are host to numerous genetic mutations. This makes them less reliable representatives of their starting tissue phenotype.

Various transformation approaches have been used in the last 30 years to overcome replicative senescence, including induction of pancreatic tumours by irradiation (Gazdar et al., 1980) or viral infection (Santerre et al., 1981), immortalisation of beta cells in vitro and development of transgenic mice with targeted expression of a recombinant oncogene in beta cells (Newgard, 1994). Few of these attempts have been successful, because cell differentiation and proliferation capacities are mutually exclusive.

Expression of the SV40 large T oncoprotein (Tag) has been the most successful (Tab. 1). SV40 T antigen is capable of adapting primary cells to continuous growth in culture and transforming cultured cells into a tumorigenic condition (Efrat and Hanahan, 1987). Efrat and co-workers (Efrat and Hanahan, 1987) detected a significant level of tumour suppressor protein 53 (p53) in all pancreatic beta cells expressing large $\mathrm{T}$ antigen in contrast to normal beta cells from RIP1-Tag transgenic mice (SV40 large T antigen expressed in islet beta cells under the control of the rat insulin promoter) where protein was undetectable. Other viral genes that have been used to immortalise cells are adenovirus E1A and E1B, human papilloma virus (HPV) E6 and E7 and Epstein Barr virus (EBV). Most of these genes probably act by blocking the inhibition of cell cycle progression by inhibiting the activity of genes such as cyclin-dependent kinase inhibitor 1 (CIP-1/WAF-1/p21), retinoblastoma protein (Rb), p53, tumour suppressor protein 16 (p16), and thus giving an opportunity for further mutations (Freshney, 2000). 
Tab. 1: Insulin-secreting cell lines from various species (modfied from Ulrich et al., 2002)

\begin{tabular}{|c|c|c|c|c|c|c|}
\hline Cell line & Cell origin & Species & Methods & Advantages & Disadvantages & References \\
\hline HIT & Insulinoma & Hamster & $\begin{array}{l}\text { SV40 T-antigen } \\
\text { transfected }\end{array}$ & $\begin{array}{l}\text { Contain membrane-bound } \\
\text { insulin granules. }\end{array}$ & $\begin{array}{l}\text { Low insulin content. } \\
\text { Only HIT-T15 responds } \\
\text { to glucose stimulation. }\end{array}$ & $\begin{array}{l}\text { (Santerre et al., } \\
\text { 1981) }\end{array}$ \\
\hline MIN6 & Insulinoma & Mouse & \begin{tabular}{|l|} 
SV40 T-antigen \\
transgenic mouse
\end{tabular} & $\begin{array}{l}\text { Express glucokinase. } \\
\text { and Glut2 }\end{array}$ & $\begin{array}{l}\text { Treatment with nicotinamide } \\
\text { makes them responsive to glucose. }\end{array}$ & $\begin{array}{l}\text { (Ishihara et al., } \\
\text { 1993) }\end{array}$ \\
\hline$\beta \mathrm{TC1}$ & Insulinoma & Mouse & $\begin{array}{l}\text { SV40 T-antigen } \\
\text { transgenic mouse }\end{array}$ & $\begin{array}{l}\text { Produce proinsulin I and II } \\
\text { and insulin. }\end{array}$ & $\begin{array}{l}\text { Hexokinase activity. Not } \\
\text { responsive to glucose stimulation. }\end{array}$ & (Efrat et al., 1988) \\
\hline IgSV195 & Insulinoma & Mouse & $\begin{array}{l}\text { SV40 T-antigen } \\
\text { transgenic mouse }\end{array}$ & $\begin{array}{l}\text { Retain certain morphological } \\
\text { and physiological } \\
\text { characteristics of } \\
\text { pancreatic beta cells. }\end{array}$ & $\begin{array}{l}\text { Need to be exposed to fetal } \\
\text { bovine serum and a combination } \\
\text { of 3-isobutyl-1-methylxanthine } \\
\text { and glutamine for insulin secretion. } \\
\text { Not responsive to glucose in } \\
\text { the physiological range. }\end{array}$ & $\begin{array}{l}\text { (Gilligan et al., } \\
\text { 1989) }\end{array}$ \\
\hline$\beta \mathrm{HC}$ & $\begin{array}{l}\text { Hyperplastic } \\
\text { islets }\end{array}$ & Mouse & $\begin{array}{l}\text { SV40 T-antigen } \\
\text { transgenic mouse }\end{array}$ & $\begin{array}{l}\text { BHC9 express GLUT2 } \\
\text { and glucokinase. Normal } \\
\text { concentration-dependency } \\
\text { curve. }\end{array}$ & $\begin{array}{l}\text { High hexokinase activity } \\
\text { developed after several } \\
\text { generations. Only clone } 9 \\
\text { responds to glucose stimulation. }\end{array}$ & $\begin{array}{l}\text { (Radvanyi et al., } \\
\text { 1993) }\end{array}$ \\
\hline NIT-1 & Insulinoma & Mouse & $\begin{array}{l}\text { NOD/Lt mouse, } \\
\text { SV40 T-antigen }\end{array}$ & $\begin{array}{l}\text { High levels of insulin } \\
\text { mRNA. }\end{array}$ & $\begin{array}{l}\text { Not responsive to glucose in } \\
\text { the physiological range. }\end{array}$ & $\begin{array}{l}\text { (Hamaguchi et al., } \\
\text { 1991) }\end{array}$ \\
\hline RINm & Insulinoma & Rat & $\begin{array}{l}\text { Radiation } \\
\text { induced }\end{array}$ & & $\begin{array}{l}\text { Insulin level decreases with } \\
\text { passages. Also secrete } \\
\text { somatostatin. Not responsive to } \\
\text { glucose stimulation. }\end{array}$ & $\begin{array}{l}\text { (Gazdar et al., } \\
1980)\end{array}$ \\
\hline RINm5F & Insulinoma & Rat & Radiation induced & & $\begin{array}{l}\text { Inappropriate sensitivity to } \\
\text { glucose. Abnormal properties of } \\
\text { glucose transport and/or } \\
\text { phosphorylation. }\end{array}$ & $\begin{array}{l}\text { (Gazdar et al., } \\
\text { 1980; } \\
\text { Praz et al., 1983) }\end{array}$ \\
\hline RINr & Insulinoma & Rat & Radiation induced & & $\begin{array}{l}\text { Inappropriate sensitivity to } \\
\text { glucose. Abnormal properties } \\
\text { of glucose transport and/or } \\
\text { phosphorylation. }\end{array}$ & $\begin{array}{l}\text { (Gazdar et al., } \\
\text { 1980; } \\
\text { Praz et al., 1983) }\end{array}$ \\
\hline $\begin{array}{l}\text { BRIN- } \\
\text { BD11 }\end{array}$ & $\begin{array}{l}\text { Insulinoma } \\
\text { and normal } \\
\beta \text {-cells }\end{array}$ & Rat & $\begin{array}{l}\text { Electrofusion } \\
\text { derived }\end{array}$ & $\begin{array}{l}\text { Express GLUT-2 and high } \\
\text { glucokinase activity. }\end{array}$ & Also express hexokinase. & $\begin{array}{l}\text { (McClenaghan and } \\
\text { Flatt, 1999) }\end{array}$ \\
\hline INS-1 & Insulinoma & Rat & Radiation induced & $\begin{array}{l}\text { Responsiveness to } \\
\text { glucose within the } \\
\text { physiological range. } \\
\text { Relatively high insulin } \\
\text { content. }\end{array}$ & $\begin{array}{l}\text { Require mercaptoethanol in } \\
\text { culture medium. }\end{array}$ & (Asfari et al., 1992) \\
\hline CRI-G1 & Insulinoma & Rat & Radiation induced & & $\begin{array}{l}\text { In parallel to insulin they release } \\
\text { glucagon. Not responsive } \\
\text { to physiological glucose } \\
\text { concentrations. }\end{array}$ & $\begin{array}{l}\text { (Carrington et al., } \\
\text { 1986) }\end{array}$ \\
\hline In-111 & Insulinoma & Rat & BK-virus induced & & $\begin{array}{l}\text { Not responsive to physiological } \\
\text { glucose concentrations. }\end{array}$ & (Uchida et al., 1979) \\
\hline $\mathrm{CM}$ & Insulinoma & Human & $\begin{array}{l}\text { from the ascitic } \\
\text { fluid of a patient } \\
\text { with liver meta- } \\
\text { stasis of a mali- } \\
\text { gnant insulinoma }\end{array}$ & $\begin{array}{l}\text { Express GLUT2 and } \\
\text { glucokinase. } \\
\text { concentrations. }\end{array}$ & $\begin{array}{l}\text { No insulin secretion in response } \\
\text { to increasing glucose }\end{array}$ & (Baroni et al., 1999) \\
\hline TRM-1 & $\begin{array}{l}\text { Foetal } \\
\text { pancreas }\end{array}$ & Human & $\begin{array}{l}\text { SV40 T-antigen, } \\
\text { H-rasval12 }\end{array}$ & Express GLUT2. & $\begin{array}{l}\text { Express small amounts of insulin } \\
\text { and glucagon. Not responsive to } \\
\text { glucose stimulation. }\end{array}$ & (Wang et al., 1997) \\
\hline Blox5 & $\begin{array}{l}\text { Foetal } \\
\text { pancreas }\end{array}$ & Human & $\begin{array}{l}\text { SV40 T-antigen, } \\
\text { H-rasval12, } \\
\text { hTERT oncogene }\end{array}$ & $\begin{array}{l}\text { Exhibit glucose responsive } \\
\text { insulin secretion. } \\
\text { Express glucokinase. }\end{array}$ & Low insulin content. & $\begin{array}{l}\text { (Dufayet de la Tour } \\
\text { et al., 2001) }\end{array}$ \\
\hline
\end{tabular}




\section{Physiology of beta cell lines}

Although the behaviour of none of the cell lines perfectly mimics primary beta cell physiology, they are extremely valuable tools for the study of molecular events underlying beta cell function and dysfunction and represent a potential source of transplantable tissue to overcome the limited availability of primary islets for this procedure.

Glucose phosphorylation is considered the main mechanism for glucose sensing in beta cells, as it couples the amount of secreted insulin to the extracellular glucose level. Normal beta cells express mainly the high-Km glucokinase isotype, which triggers insulin secretion only when the extracellular glucose concentration exceeds a physiological threshold.

Although insulinoma-derived cell lines have the advantage of unlimited growth in tissue culture, many exhibit vast differences in their insulin-secretory responsiveness to glucose compared to normal beta cells. These changes in functional characteristics represent dedifferentiation of the cell. Some of these cell lines produce significant amounts of insulin, up to $30 \%$ of those found in normal beta-cells, and release it in response to glucose stimulation. However, only a few cell lines show a normal response to glucose concentrations in the physiological range; most transformed beta cell lines manifested hypersensitivity to glucose (Efrat, 2004). HIT and $\beta$ TC cells secrete insulin in response to glucose with a marked shift to higher sensitivity of the concentration dependence curve, while $\beta$ HC-9, MIN6, INS-1 and Blox5 retain normal glucose regulation of insulin release.

One important deviation from the normal phenotype that cell lines often incur during the first 20 passages in culture, which leads to an insulin secretory response to subphysiological glucose levels, is the induction of the low-Km glucose-phosphorylating enzyme hexokinase. The mechanism responsible for the increase in hexokinase mRNA and activity is not known; however it is thought that it results from the increased metabolic requirements of the dividing cells, as hexokinase may be more efficient than glucokinase in providing energy from glucose metabolism to the proliferating beta cells. The increase in hexokinase activity represents a serious obstacle in the development of beta cell lines for cell therapy of diabetes, since transplantation of such cells might result in hypoglycaemia (Efrat, 1999).

See Table 1 for the most important and the most often used insulin-secreting cell lines from various species among which MIN6 and INS1 cell lines best reflect the physiological conditions since they respond to glucose stimulation and express glucokinase.

\subsection{Insulin-secreting cell lines}

Attempts have been made to develop stable insulin-secreting cell lines from spontaneous insulinomas of human or animal origin, but only a few studies report the use of such cell lines (Wollheim et al., 1990). Naturally occurring beta cell tumours dedifferentiate very rapidly in vitro and lose their ability to synthesise and secrete insulin.

The most widely used tumour cell lines are radiation- or virusinduced insulinomas. Beta-hyperplastic islet-derived cells $(\beta \mathrm{HC})$ and hamster pancreatic beta cells (HIT) cells were derived from preneoplastic islet cells transformed with SV40, while rat insulinoma cell line (RIN), insulinoma cell line (INS-1) and Cambridge rat insulinoma-G1 cell line (CRI-G1) were generated from irradiated cells (Efrat et al., 1988; Gilligan et al., 1989; Ishihara et al., 1993; Radvanyi et al., 1993). Although all these cell lines represent transformed cells, they have retained some characteristics of normal beta cells. In most cell lines hormone secretion was high at the beginning but decreased with time in culture (Ulrich et al., 2002) and the capacity to respond to glucose is high at low or intermediate passages, but this property may be lost at higher passages. Since tumour cell lines display a defective phenotype, repair of defective gene expression was used to generate beta cell lines that respond to secretagogues in the physiological range.

\subsubsection{Rat insulinoma cell line (RIN)}

The first cell lines obtained, termed RINr and RINm, were initiated from tumours maintained in rats. RINm5F cells were derived from the NEDH (New England Deaconess Hospital) rat insulinoma induced by high-dose X-ray irradiation. Their physiological characteristics differ from native beta cells. These cells are one of most widely used insulin-secreting cell lines and contain mainly insulin and small amounts of glucagon and somatostatin. Abnormal properties of glucose transport and/ or phosphorylation have been reported for RINm5F and $\mathrm{RINr}$ cells, and both also exhibit inappropriate sensitivity to glucose (Halban et al., 1983).

\subsubsection{Insulinoma cell line (INS-1)}

In 1992, Asfari and co-workers (Asfari et al., 1992) generated the insulinoma cell line INS-1, which displays many important characteristics of the pancreatic beta cell, including a high insulin content and responsiveness to glucose (associated with expression of GLUT-2 and glucokinase) within the physiological range. INS-1 cells are derived from a rat insulinoma induced by X-ray irradiation. They synthesise both proinsulin I and II. Although INS-1 seem to respond to the physiological range of glucose, they are still proliferative, but the total insulin content is only $20 \%$ of that of the native cells (Asfari et al., 1992).The serious disadvantage of these cells is that they require mercaptoethanol (which is toxic and irritating and irreversibly denatures the proteins) in their culture media. Without this component the cells cannot be propagated and lose many important functional characteristics (Asfari et al., 1992).

Merglen and co-workers have isolated clonal INS1E cells from the parenteral cells. These cells display stable differentiated beta cell phenotype over 116 passages and are able to secrete insulin in response to elevated glucose concentrations. Their concentration-dependence curve is similar to that of rat islets (Merglen et al., 2004).

\subsection{Transformed beta cell lines and insulin-secreting beta cell lines derived from transgenic mice}

Progress in transgenic technology has enabled the invention of new cell lines from transgenic animals, which express an on- 
cogene under the control of the insulin promoter. The level of expression of the introduced gene can vary in different clones, probably as a function of the insertion site of the recombinant chromosomal DNA. To ensure a constant and high level of expression, constitutive promoters are generally used. Most of these are of viral origin, such as the cytomegalovirus promoter (CMV), the Rous sarcoma long-terminal repeat (LTR) sequence and the SV40 early gene promoter (Soria et al., 2000).

In most cases an SV40 T-antigen has been used. SV40 or Simian vacuolating virus 40 , a circular DNA virus of rhesus monkey origin, is a member of the polyomavirus. It is one of the most intensively studied viral systems that infect eukaryotic cells and have the potential to cause tumours. The virus replicates vegetatively in cells of the African green monkey and is capable of transforming a variety of cell lines including human cells. It is believed to suppress the transcriptional properties of the tumour-suppressing p53, which is responsible for initiating apoptosis. A mutated p53 gene may contribute to uncontrolled cellular proliferation, leading to a tumour.

\subsubsection{Transgenic C57BL/6 mouse insulinoma cell line (MIN)}

MIN-6 cells originate from a transgenic C57BL/6 mouse insulinoma expressing an insulin-promoter/T-antigen construct. They form islet-like cells. MIN-6 cells express GLUT-2 and glucokinase and respond to glucose within the physiological range in the presence of nicotinamide (Miyazaki et al., 1990). Sometimes a sudden loss of glucose-induced insulin secretion from MIN6 cells during the course of the passages is noticed, possibly due to an outgrowth of cells with a poor response to glucose or a reduced expression of the genes responsible for glucose-induced insulin secretion (Miyazaki et al., 1990).

\subsubsection{Hamster pancreatic beta cells (HIT)}

HIT-T15 cells were produced by simian virus 40 (SV40) transformations of hamster pancreatic beta cells followed by serial cloning (Santerre et al., 1981). HIT-T15 cells have modest numbers of membrane-bound secretory granules, which is characteristic of mature beta secretory granules in normal hamster beta cells. The presence of insulin was confirmed by immunofluorescence antibody staining. In comparison to normal hamster islets, which contain about $56 \mu \mathrm{g}$ of insulin per $\mathrm{mg}$ protein, the insulin content of HIT cells is about 2.5 - 20 times lower. Proinsulin biosynthesis and processing appear to function normally in HIT cells. The cells respond to a variety of compounds known to modulate insulin release in normal islets. Concentration-dependence curves for glucose-stimulated insulin release were quite similar between HIT cells and hamster islets, peak stimulation being achieved at 7.5-10 mM glucose. This is considerably less than the $16.7 \mathrm{mM}$ glucose required for maximal stimulation of rat islets (Santerre et al., 1981).

\subsubsection{Beta-hyperplastic islet-derived cells ( HC)}

$\beta \mathrm{HC}-9$ cells were generated from hyperplastic pancreatic islets of transgenic mice expressing a SV40 T-antigen under the control of the insulin promoter. This cell line is characterised by a normal concentration-dependency curve for glucose-stim- ulated insulin release and expresses GLUT-2 and glucokinase. In the $\beta \mathrm{HC}-9$ cell line, the kinetic characteristics of glucose use, glucose oxidation and glucose-induced oxygen consumption are similar to those of glucose phosphorylation, indicating that the kinetics of glucose metabolism from the glucose phosphorylation step in the cytosol to the mitochondrial process of oxidative phosphorylation are determined by the glucosephosphorylating enzyme glucokinase in $\beta \mathrm{HC}-9$ cells (Liang et al., 1996).

\subsubsection{Beta-tumour cells ( TC)}

In recent years a number of highly differentiated beta cell lines termed beta-tumour cells ( $\beta$ TC) were derived by expression of the SV40 T antigen (Tag) oncoprotein under control of the insulin promoter in transgenic mice or rats (Efrat, 1999). This results in the specific expression of T-antigen (Tag) in beta cells and subsequent immortalisation of these cells (Soria et al., 2000). $\beta$ TC cells produce both proinsulin I and II and efficiently process each into mature insulin. Secretory granules, in which insulin is stored, were identified by electron microscopy. The cells secrete insulin with a lower threshold for maximal stimulation than that of normal beta cells, and they maintain the features of differentiated beta cells for about 50 passages in culture. $\beta$ TC lines can be repeatedly derived from primary beta cell tumours that heritably arise in the transgenic mice. Thus, targeted expression of an oncogene with a cell-specific regulatory element can be used both to immortalise a rare cell type and to provide a selection for the maintenance of its differentiated phenotype (Efrat et al., 1988). This manipulation allows regulated cell expansion or growth arrest, as needed (Efrat, 1999). Following more than 60 passages in vitro, BTC-tet (insulinoma cell line derived from transgenic mice expressing a tetracycline-regulated oncogene) cells develop a high hexokinase activity, resulting in an insulin secretory response to subphysiological glucose levels. However, following 2-4 weeks of growth arrest, which presumably decreases the metabolic requirements of the cells, the hexokinase activity was downregulated several fold. This finding confirms the correlation between cell proliferation and high hexokinase activity in the $\beta \mathrm{TC}$ lines, and demonstrates that growth arrest allows restoration of the normal pattern of glucose phosphorylation, which is key to correct glucose sensing and accurate insulin secretion (Efrat, 1999).

\subsection{Insulin-secreting cells of non-islet cell origin}

A few years ago the AtT-20 cell line was engineered from ACTHsecreting cells of the anterior pituitary (Newgard, 1994). Stable transfection of AtT-20 cells with a construct in which a viral promoter was used to direct expression of the human proinsulin cDNA resulted in cell lines which secreted fully processed insulin (Newgard, 1994).

AtT-20 cells do not respond to glucose as a secretagogue, and although these cells express the glucokinase gene, glucokinase activity is either extremely low or absent (McClenaghan and Flatt, 1999). Stable transfection of AtT-20 cells with a plasmid containing the GLUT-2 cDNA linked to the cytomegalovirus promoter resulted in high levels of expression of the GLUT-2 
protein. The same approach was used in RINm5F cells transfected with human GLUT-2 transporter cDNA under the control of a viral promoter (Tiedge et al., 1993).

\section{Quality control of beta cell lines}

When a new cell line is derived details of its origin are required. Cell line characterisation is important to ensure that cells have the correct identity and phenotype. This is critical for reliable research and to ensure valid data from cell-based assays.

To confirm species origin chromosomal analysis can be performed. Karyology visualises the entire genome and enables rapid identification of the species of origin. The chromosomes are commonly viewed by arresting the cells at metaphase in which chromosomes are highly condensed and can be visualised by staining to reveal banding patterns (Stacey et al., 2007).

In native beta cells several key molecules are responsible for glucose-induced insulin secretion. Gene expression analysis of glucose sensing molecules (glucose transporters, glucokinase) and expression of genes involved in regulated exocytosis (SNARE proteins, insulin genes) can be identified by RTPCR.

To determine the presence of insulin-containing secretory granules ultrastructural analysis and immune-electron microscopic analysis for insulin can be used. Immunohistochemical or immunofluorescent characterisation of insulin-secreting beta cells can be performed using specific antibodies (insulin and proinsulin polyclonal antibodies). Synthesis and processing of insulin can be detected by reversed phased HPLC analysis. Concentration dependence of glucose stimulated insulin secretion shows whether insulin secretory properties in the cell line are similar to those in native pancreatic beta cells.

\section{Conclusions}

Abnormalities in insulin secretion are involved in a number of diseases, including type 1 and type 2 diabetes, persistent hyperinsulinemic hypoglycaemia of infancy and insulinoma. Understanding the mechanisms that regulate insulin secretion may allow the development of new therapies for these diseases as well as contribute to our ability to engineer insulin-producing cells for a cell replacement therapy of type 1 diabetes.

Understanding the mechanisms that regulate insulin secretion is important for the development of new drugs and to generate substituted insulin-producing cells. Glucose phosphorylation in beta cells has been viewed as a key regulatory event in coupling insulin secretion to extracellular glucose concentrations. Work with transformed rodent beta cell lines as well as recent findings (Efrat, 2004) from human progenitor cells induced to differentiate into insulin-producing cells has provided new insights into the role of glucose phosphorylating enzymes in the regulation of insulin secretion.

Despite problems associated with pancreatic beta cell cultures, these cell lines have provided valuable information about physiological, pathophysiological and differentiation processes in these cells. In spite of that there is an urgent need to establish a "normal" not cancerogenic beta cell line of a human or pig origin either by establishment of a spontaneously transformed stable cell line directly from the healthy pancreas or by the use of stem cells.

\section{References}

Asfari, M., Janjic, D., Meda, P. et al. (1992). Establishment of 2-mercaptoethanol-dependent differentiated insulin- secreting cell lines. Endocrinology 130, 167-178.

Ashcroft, F. M. and Rorsman, P. (1989). Electrophysiology of the pancreatic beta-cell. Prog. Biophys. Mol. Biol. 54(2), 87143.

Baroni, M. G., Cavallo, M. G., Mark, M. et al. (1999). Beta-cell gene expression and functional characterisation of the human insulinoma cell line CM. J. Endocrino. 161, 59-68.

Berne, R. M. (1998). Physiology (4th ed.). St. Louis: Mosby.

Carrington, C.A., Rubery, E. D., Pearson, E. C. and Hales, C. N. (1986). Five new insulin-producing cell lines with differing secretory properties. J. Endocrino. 109(2), 193-200.

Dean, P. M. and Matthews, E. K. (1968). Electrical activity in pancreatic islet cells. Nature 219(5152), 389-390.

Dudek, R. W. (2007). High-yield embryology (3rd ed.). Baltimore, MD: Lippincott Williams \& Wilkins.

Dufayet de la Tour, D., Halvorsen, T., Demeterco, C. et al. (2001). Beta-cell differentiation from a human pancreatic cell line in vitro and in vivo. Mol. Endocrino. 15, 476-483.

Efrat, S. (2004). Regulation of insulin secretion: insights from engineered beta-cell lines. Ann. N Y Acad. Sci. 1014, 88-96.

Efrat, S. (1999). Genetically engineered pancreatic beta-cell lines for cell therapy of diabetes. Ann. N Y Acad. Sci. 875, 286-293.

Efrat, S., Linde, S., Kofod, H. et al. (1988). Beta-cell lines derived from transgenic mice expressing a hybrid insulin geneoncogene. Proc. Natl. Acad. Sci. USA 85(23), 9037-9041.

Efrat, S. and Hanahan, D. (1987). Bidirectional activity of the rat insulin II 5'-flanking region in transgenic mice. Mol. Cell. Biol. 7(1), 192-198.

Elayat, A. A., el-Naggar, M. M. and Tahir, M. (1995). An immunocytochemical and morphometric study of the rat pancreatic islets. J. Anat. 186, 629-637.

Freshney, R. I. (2000). Culture of animal cells: a manual of basic technique (4th ed.). New York: Wiley-Liss.

Gazdar, A. F., Chick, W. L., Oie, H. K. et al. (1980). Continuous, clonal, insulin- and somatostatin-secreting cell lines established from a transplantable rat islet cell tumor. Proc. Natl. Acad. Sci. USA 77(6), 3519-3523.

Gilligan, A., Jewett, L., Simon, D. et al. (1989). Functional pancreatic beta-cell line from SV40 T-antigen transgenic mouse. Diabetes 38(8), 1056-1062.

Gruber, F. P. and Hartung, T. (2004). Alternatives to animal experimentation in basic research. ALTEX 21, Suppl. 1, 3-31.

Halban, P.A., Praz, G. A. and Wollheim, C. B. (1983). Abnormal glucose metabolism accompanies failure of glucose to stimu- 
late insulin release from a rat pancreatic cell line (RINm5F). Biochem. J. 212(2), 439-443.

Hamaguchi, K., Gaskins, H. R. and Leiter, E. H. (1991). NIT-1, a pancreatic beta-cell line established from a transgenic NOD/ Lt mouse. Diabetes 40(7), 842-849.

Ishihara, H., Asano, T., Tsukuda, K. et al. (1993). Pancreatic beta cell line MIN6 exhibits characteristics of glucose metabolism and glucose-stimulated insulin secretion similar to those of normal islets. Diabetologia 36(11), 1139-1145.

Jo, J., Choi, M. Y., and Koh, D.-S. (2007). Size distribution of mouse Langerhans islets. Biophysical J. 93(8), 2655-2666.

Koolman, J. and Röhm, K.-H. (2005). Color atlas of biochemistry (2nd ed.). Stuttgart, New York: Thieme.

Kwan, E. P., Xie, L., Sheu, L. et al. (2006). Munc13-1 deficiency reduces insulin secretion and causes abnormal glucose tolerance. Diabetes 55(5), 1421-1429.

Liang, Y., Bai, G., Doliba, N. et al. (1996). Glucose metabolism and insulin release in mouse beta HC9 cells, as model for wild-type pancreatic beta-cells. Am. J. Physiol. Endocrinol. Metab. 270(5), 846-857.

McClenaghan, N. H. and Flatt, P. R. (1999). Engineering cultured insulin-secreting pancreatic beta-cell lines. J. Mol.Med. 77(1), 235-243.

Merglen, A., Theander, S., Rubi, B. et al. (2004). Glucose sensitivity and metabolism-secretion coupling studied during two-year continuous culture in INS-1E insulinoma cells. Endocrino. 145(2), 667-678.

Miyazaki, J., Araki, K., Yamato, E. et al. (1990). Establishment of a pancreatic beta cell line that retains glucose-inducible insulin secretion: special reference to expression of glucose transporter isoforms. Endocrino. 127(1), 126-132.

Neher, E. and Marty, A. (1982). Discrete changes of cell membrane capacitance observed under conditions of enhanced secretion in bovine adrenal chromaffin cells. Proc. Natl. Acad. Sci. USA 79(21), 6712-6716.

Newgard, C. B. (1994). Cellular engineering and gene therapy strategies for insulin replacement in diabetes. Diabetes 43(3), 341-350.

Paulmann, N., Grohmann, M., Voigt, J. r.-P. et al. (2009). Intracellular serotonin modulates insulin secretion from pancreatic beta-cells by protein serotonylation. PLoS Biol. 7(10), e1000229.

Praz, G. A., Halban, P. A., Wollheim, C. B. et al. (1983). Regu- lation of immunoreactive-insulin release from a rat cell line (RINm5F). Biochem. J. 210(2), 345-352.

Radvanyi, F., Christgau, S., Baekkeskov, S. et al. (1993). Pancreatic beta-cells cultured from individual preneoplastic foci in a multistage tumorigenesis pathway: a potentially general technique for isolating physiologically representative cell lines. Mol. Cel. Biol. 13, 4223-4232.

Santerre, R. F., Cook, R. A., Crisel, R. M. et al. (1981). Insulin synthesis in a clonal cell line of simian virus 40-transformed hamster pancreatic beta cells. Proc. Natl. Acad. Sci. USA 78(7), 4339-4343.

Soria, B., Andreu, E., Berna, G. et al. (2000). Engineering pancreatic islets. Pflugers Arch.440(1), 1-18.

Stacey, G. N., Byrne, E. and Hawkins, J. R. (2007). DNA Fingerprinting and Characterization of Animal Cell Lines. In Animal Cell Biotechnologyl. 24, 123-145.

Tiedge, M., Hohne, M. and Lenzen, S. (1993). Insulin secretion, insulin content and glucose phosphorylation in RINm5F insulinoma cells after transfection with human GLUT2 glucose-transporter cDNA. Biochem. J. 296, 113-118.

Uchida, S., Watanabe, S., Aizawa, T. et al. (1979). Polyoncogenicity and insulinoma-inducing ability of BK Virus, a human Papovavirus, in Syrian golden hamsters. J. Natl. Cancer Inst. 63, 119-126.

Ulrich, A. B., Schmied, B. M., Standop, J. et al. (2002). Pancreatic cell lines: a review. Pancreas 24(2), 111-120.

Wang, S., Beattie, G. M., Mally, M. I. et al. (1997). Isolation and characterization of a cell line from the epithelial cells of the human fetal pancreas. Cell Transplant. 6(1), 59-67.

Wollheim, C. B., Meda, P. and Halban, P. A. (1990). Establishment and culture of insulin-secreting beta cell lines. Methods Enzymol. 192, 223-235.

\section{Correspondence to}

Avrelija Cencič, $\mathrm{PhD}$

Dept. of Microbiology, Biochemistry, Biotechnology

Faculty of Agriculture and Life Sciences

University of Maribor

Pivola 10

2311 Hoce

Slovenia

e-mail: avrelija.cencic@uni-mb.si 